MirosŁaw Wójtowicz, Tomasz Rachwat

Pedagogical University of Cracow, Poland

\title{
Globalization and New Centers of Automotive Manufacturing - the Case of Brazil, Mexico, and Central Europe
}

\begin{abstract}
The globalization of the automotive industry in the last twenty years has manifested itself in a rapid increase in the assembly of automobiles and the production of automotive components and spare parts outside of the traditional centers of automotive manufacturing. On the basis of contemporary research and literature, we can distinguish two types of emerging centers of automobile manufacturing. First are potentially large domestic markets with a low level of motor vehicle ownership and rapidly growing economy such as Brazil. The second type of new automobile manufacturing center consists of the peripheries of automotive core regions such as Mexico in the case of the North American core region and Central Europe in the case of the Western European core region. These new growth centers have benefitted from their lower production costs compared to those of core regions and their geographic proximity to the largest automobile markets. These emerging centers of manufacturing have become attractive locations, especially for export-oriented manufacturing facilities operated by large transnational automotive corporations attempting to improve their global competitiveness. The purpose of this paper is to evaluate the effect of foreign direct investment on the development of automobile production in these three emerging regions. The paper reviews post-1990 production trends and changes in the geography of automobile production, especially new greenfield investments in the three analyzed regions. We examine changes in international trade in Brazil, Mexico and Central Europe with a focus on automobiles and automobile parts. Based on the results of our research, we determine the effects of foreign direct investment and industrial upgrading on the role of these emerging production centers in the global production system.
\end{abstract}

Key words: automotive industry; Brazil; Central Europe; FDI; globalization; industrial upgrading; Mexico

\section{INTRODUCTION}

The automotive industry is often cited as an example of a strongly globalized industry, which attempts to standardize its products across many global markets. This makes it possible for its constituent transnational corporations to maximize their economies of scale and minimize costs associated with the introduction of new models. The shift from national automotive industries to global automotive industries began in the late 1980s (Lung, van Tulder 2004; Stanford, 2010). 
It is also noteworthy that attempts in the late 1990s by General Motors and Fiat to introduce standardized automobile models across multiple markets failed. This helped to confirm the regional nature of automotive markets, which differ in terms of preferences for vehicle appearance, size, price, and special features. According to industry analysts, automotive manufacturing is growing especially fast in economically integrated geographic regions such as the European Union, most of North America (NAFTA), and most of South America (MERCOSUR). Automotive companies are also key lobbyists on behalf of regional integration and tend to spearhead regional initiatives focused on integration (Lung, van Tulder, 2004).

In order to secure the most favorable position in integrating regional markets, automotive corporations tend to create regional production systems designed to satisfy the specific needs of each regional market (Freyssenet, Lung, 2004). A full characterization of today's automotive industry needs to cover four levels of spatial concentration of business activity in the sector, starting with local production clusters, national level concentration, regional concentration, and global scale. Unique business conditions at each level of analysis also need to be considered (Fig. 1). Major automotive manufacturers tend to attract suppliers including component manufacturers, which choose to establish facilities close to vehicle assembly plants. This leads to the formation of regional automotive manufacturing clusters.

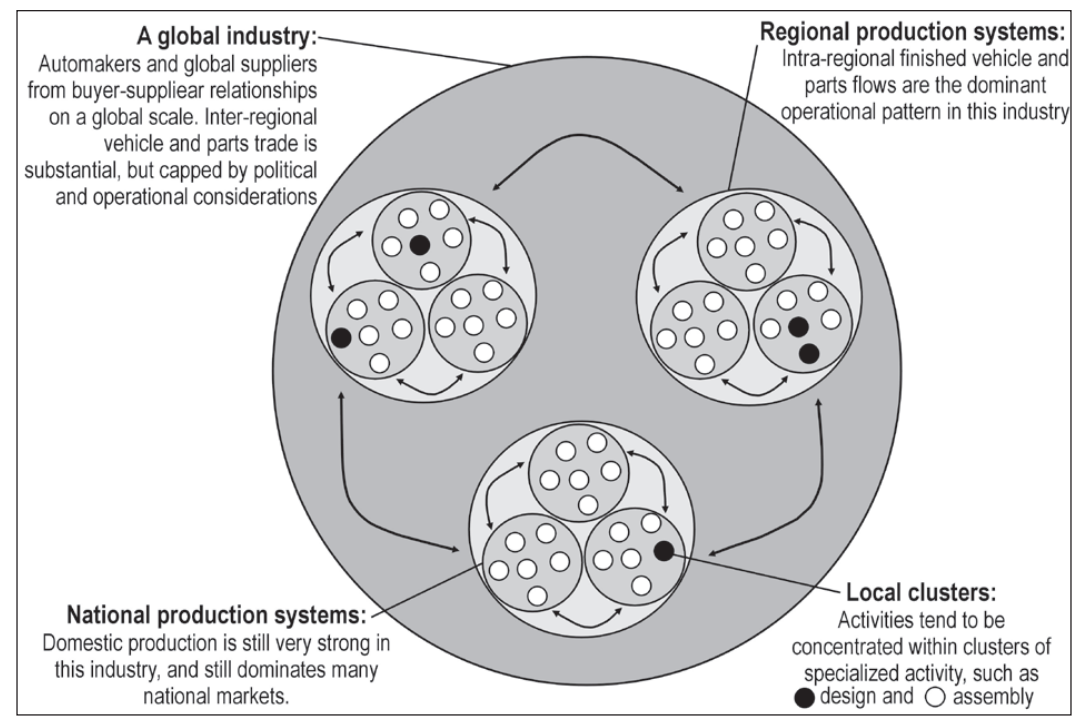

Fig. 1. Linkages in the automotive industry at selected spatial levels

Source: Sturgeon et al., 2008: 304

This type of multiplier effect is widespread in the automotive industry, which is primarily the result of the most extensive network of links formed because of the substantial size of its output and the complexity of a product such as the automobile (Rachwat, Wiedermann, 2008). The shift to regional manufacturing in the automotive sector occurs especially quickly 
in situations where an economically integrated region is relatively impermeable to imports and at the same time large enough to absorb large product volumes at strongly profitable price points. Another key driver of regional automotive manufacturing is social and economic development in emerging economies whose citizens are now wealthy enough to own automobiles. The latter trend has forced global automotive corporations to adapt their products to reflect the needs of less developed markets and to establish manufacturing plants closer to these new markets (Sturgeon et al., 2008; van Tulder, Audet, 2004; Klimkowska, 2011; Łasak, 2013).

In light of the unique nature of automotive markets in emerging economies, two types of global regions characterized by rapid growth in this sector have been identified. The first type of region is one featuring a potentially large internal market, low level of automobile ownership, and fast growing economy. The example used in this paper is that of Brazil, which is the most populous and economically developed country in the MERCOSUR region. Other examples of this type of region include Brazil, China, India, and Russia. The four countries are also known by the acronym BRIC. The second type of region is a peripheral region found on the fringes of core automotive regions. Many such peripheral regions have been slowly integrating with their adjacent core regions in recent decades.

The examples used in this paper are those of Mexico, an emerging economy growing adjacent to the United States and Canada as part of the regional NAFTA system, as well as Central Europe, a collection of emerging economies growing next to the cradle of the automotive sector - Western Europe. Central Europe is also integrating politically and economically with Western Europe as part of the European Union. Rapid growth of the automotive sector in Type 1 regions is largely the result of growing internal demand, which drives manufacturing growth and attracts outside investment in the sector. Growth in the automotive sector in Type 2 regions is largely the result of close geographic proximity to core automotive markets. In the case of Mexico, the core markets are the United States and Canada. In the case of Central Europe, the core markets are the old 15 member states of the European Union. Another reason for the shift of the automotive sector towards Type 2 regions is the opportunity to lower production costs thanks to lower labor costs (Pavlínek, Ženka, 2011).

The purpose of the paper is to describe changes in manufacturing output and trade in the automotive sector in selected countries in Latin America and Central Europe, changes in foreign direct investment (FDI) in the study area, and the effect of FDI on manufacturing output and industrial upgrading. The paper also describes changes in the spatial distribution of automotive manufacturing plants in the study area and identifies new centers of growth driven by new investment in the study area. The research study covers Brazil, Mexico, and Central European nations such as the Czech Republic, Hungary, Poland, Romania, Slovakia, and Slovenia. All six nations are now members of the European Union. The study period is the years 1990 to 2012. Not all relevant data were available for the entire study period; hence, parts of the analysis focus on shorter periods of time. 


\section{HistoricAL BACKGROUND}

The second half of the 1980s was a very difficult period for the automotive industry in Brazil, Mexico, and Central Europe. Both Brazil and Mexico experienced an economic crisis and hyperinflation, which reduced domestic automobile sales and consequently domestic production as well. Outdated manufacturing technologies and models made exports increasingly less likely. In light of declining domestic demand, automobile manufacturing output in Brazil and Mexico experienced a slowdown. With production on the decline, employment reductions became the expected norm. Low labor productivity further helped usher in reductions in employment. Poor economic conditions in the late 1980s forced Brazil and Mexico to abandon their earlier strategy of import substitution industrialization (Laplane, Sarti, 1997; Covarrubias, 2011; Wójtowicz, 2008, 2012).

The 1990s began with a gradual shift towards a more liberal economic policy, as outlined in the so-called Washington Consensus. The trend towards economic liberalization proved to be popular both in Brazil and Mexico, as well as Central Europe. The key points of this strategy are liberalization of foreign trade, opening of markets to direct investment, privatization of state enterprises, and far-reaching reduction in government involvement in the labor market and the economy in general. Another key factor behind changes in the automotive industry in Brazil and Mexico was regional integration in the form of MERCOSUR (1991) in Latin America and NAFTA (1994) in North America.

The first attempt at integration in Central Europe was CEFTA - Central European Free Trade Agreement - which went into effect in December 1992. The organization served as a Central European precursor to the European Union, the organization the region ultimately wished to join. Regional economic unions and the social and economic integration they tended to yield helped alter the strategies of global automotive corporations (Carrillo, 2004; Freyssenet, Lung, 2004; Laplane, Sarti, 2004; Wójtowicz, 2009). The next part of the paper will address historical issues, economic issues, and industrialization policy in the studied countries.

\section{BRAZIL - THE LEADER OF THE GROWING MERCOSUR AUTOMOBILE MARKET}

The automotive industry in Brazil has been dominated by American and European manufacturers since its inception in the 1950s. The industry has been undergoing restructuring and modernization since the late 1980s. New plants have also emerged - many are owned by Japanese, Korean, Indian, and European automotive corporations new to Brazil (Shapiro, 1991; Wójtowicz, 2008; Dorocki, 2010). While Brazil's government did invest in the automotive sector in the 1950s and 1960s, the country opened its market to global corporations in the late 1960s. These corporations have come to dominate the Brazilian market ever since (Lasak, 2013).

While Brazil has been open to the liberalization of foreign trade since the early 1990s, its government continues to make an effort to attract new investors and helps promote companies that do shift their manufacturing to Brazil. The ultimate business magnet is supposed to be the 
country's relatively large domestic market, which continues to expand as the Brazilian population becomes increasingly wealthy. Brazil's automotive industry is generally focused on the domestic market and some exports to other South American nations. Three principal stages of development have been identified for the last two decades for the Brazilian automotive industry based on changes in manufacturing output, sales, and foreign trade (Wójtowicz, 2012).

The first stage includes the period 1990-1998 and is associated with the transition from the import substitution industrialization model to the trade liberalization model based on foreign investment and limited government involvement in the economy. Brazil was also experiencing hyperinflation in the early 1990s, which was eventually reduced thanks to the Plan Real in 1994. This first stage was characterized by rapid growth in manufacturing output and the influx of new investment.

Inflation subsided in 1994 and Brazilian currency appreciated markedly. This created a new threat to Brazil's automotive industry - automobile imports. A total of 369,000 automobiles were imported in 1995 and were valued at close to 4.8 billion U.S. dollars, which created a large trade deficit for Brazil (Figs. 2 and 3). Brazil's government decided to help protect the domestic automotive sector by increasing collaboration with other South American nations as part of the MERCOSUR agreement and by signing the Automobile Agreement (Regime Automotivo). The latter was a clear signal to automobile manufacturers that the Brazilian government viewed the sector as strategically important and would help sustain its development by protecting it from strong foreign competition (Laplane, Sarti, 2004; Wójtowicz, 2012).

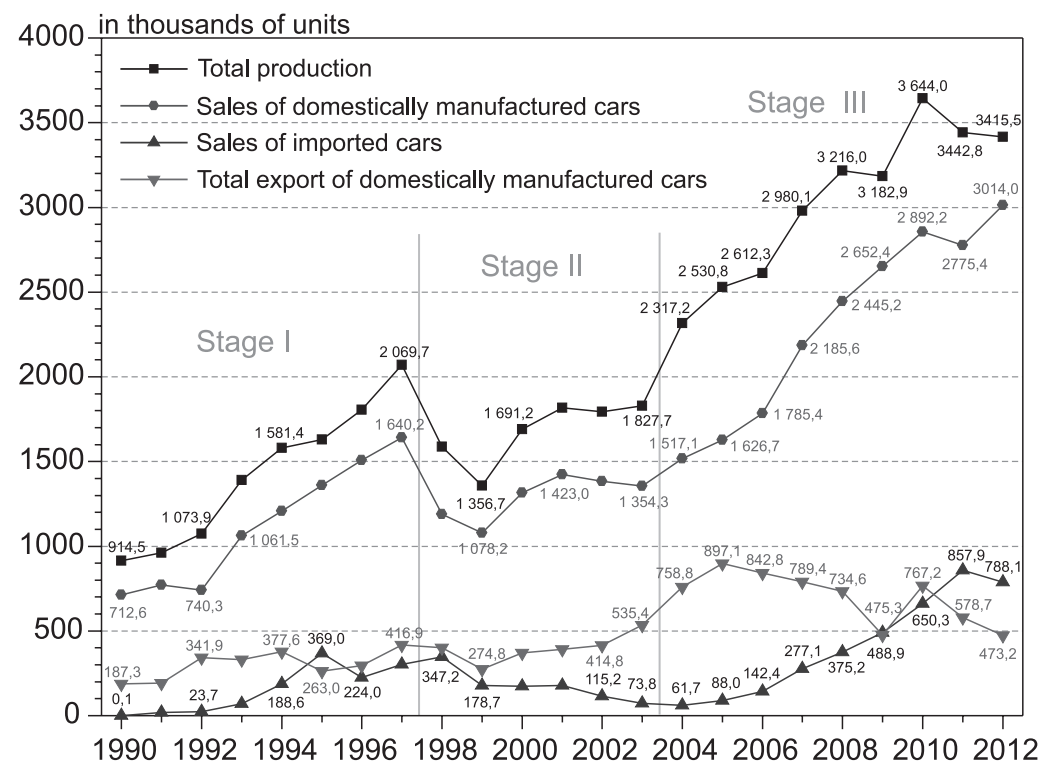

Fig. 2. Brazil - production, sales and exports of automobiles in years 1990-2012

Source: own elaboration based on Anuário da Indústria Automobilística Brasileira 2013, ANFAVEA, 2013 


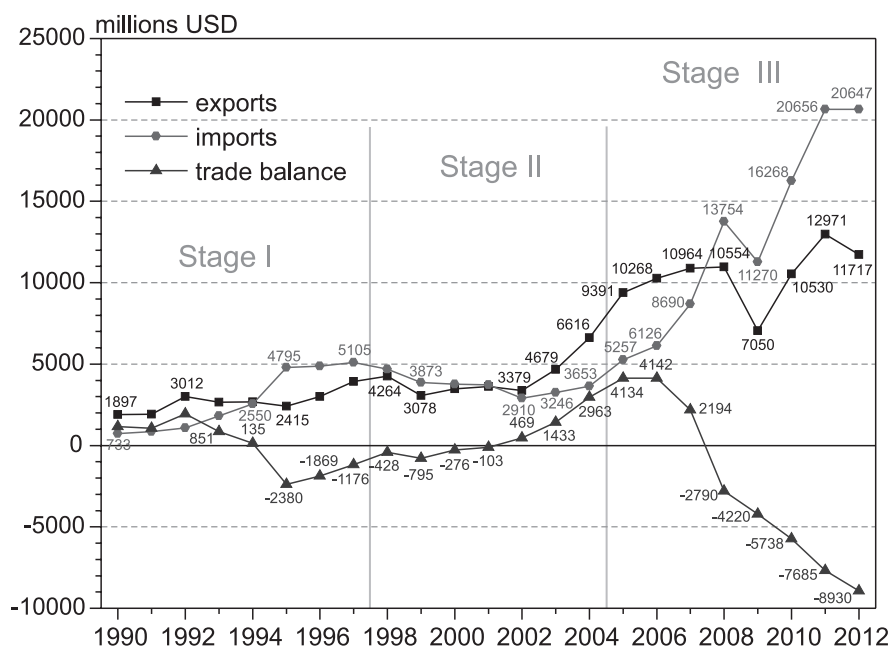

Fig. 3. Brazil: international trade - the automobile industry in years 1990-2012

Source: own elaboration based on of Anuário da Indústria Automobilística Brasileira 2013, ANFAVEA, 2013

The second stage includes the period 1998-2003 and is associated with the financial crisis in Brazil and the country's subsequent economic recession. This stage is characterized by a decrease in automobile manufacturing output to 1.36 million vehicles in 1999 and then a small increase and stagnation in the period 2001-2003 (approx. 1.8 million vehicles). The second stage began with the Asian Crisis, which later also affected Russia, Brazil, and Argentina. The crisis in Brazil led to a significant decline in new automobile purchases, which forced automotive companies in Brazil to search for export markets in order to fully utilize their newly expanded production capacity. The decrease in sales in Brazil was driven by the devaluation of the Brazilian real in 1999, which limited demand for new automobiles (van Tulder, Audet, 2004).

Brazilian automobile exports increased markedly during the second stage - more than 535,000 automobiles were exported in 2003. At the same time, automobile imports were limited to 73,800 items in 2003, compared with more than 347,000 in 1998 (Fig. 2). Brazil's automotive industry regained a positive trade balance at more than 1.4 billion U.S. dollars in 2003 (Fig. 3). The increase in Brazilian automobile exports was made possible by the modernization of existing manufacturing facilities and the construction of new plants on par with plants in Western Europe and North America. These new and improved Brazilian automobiles could now compete in world markets, and their competitiveness only increased with the devaluation of the Brazilian currency (Wójtowicz, 2012).

The third stage includes the period 2004-2012 and is characterized by rapid growth in manufacturing output, with more than 3.64 million automobiles produced in 2010, which is $99.4 \%$ more than in 2003. Manufacturing output is reduced to 3.4 million units in 2011 and 2012, which is largely the result of reduced exports of Brazilian automobiles rather than 
reduced domestic sales (Fig. 2). The currently observed manufacturing boom in Brazil may be interpreted in terms of increased economic development, which translates into the creation of wealth and the purchase of new automobiles. Not even the global financial crisis that affected the worldwide automotive industry could slow down Brazil's automotive sector. In contrast to Mexico, where production decreased significantly in 2009, Brazil's production of automobiles decreased only one percent due to reduced exports. On the other hand, production for the domestic market increased by 9.1\% (Wójtowicz, 2011).

Increased domestic sales in Brazil in recent years propelled domestic production, but also helped drive new automobile imports, which increased more than twelve-fold between 2004 and 2012 from 61,700 units to 788,100 units (Fig. 2). In the same time period, exports of Brazilian automobiles decreased due to increased domestic sales and the appreciation of the real. This led to a general decrease in the price competitiveness of Brazilian products in the global marketplace. Despite the number of automobiles exported exceeding the number imported (Fig. 2), which was the case until 2010, Brazil's automobile trade balance became negative in 2008 and reached 8.9 billion U.S. dollars in 2012. This is due to the fact that Brazil exports its specialty, mostly compacts and subcompacts, which sell for much less than the larger and more luxury vehicles that Brazilians tend to import. Ultimately, this leads to a negative trade balance (Fig. 3).

The increase in Brazilian automobile production was made possible by increased foreign direct investment by global automotive corporations and component manufacturers. This resulted in modernization of existing plants and establishment of new plants, which significantly increased total production capacity in Brazil. More than 71.7 billion U.S. dollars were invested by foreign corporations operating in Brazil in the period 1990-2012. About $61.3 \%$ (43.9 bln USD) of that was invested in manufacturing of automobiles and $38.7 \%$ was invested in manufacturing of automobile parts (27.8 bln USD) (Fig. 4). This confirms the relatively unique nature of the Brazilian automotive market, with foreign corporations entering the market primarily to manufacture finished vehicles. Investment in suppliers and component manufacturers would follow later in the form of multiplier effects driven by the need for fast and reliable delivery. The Brazilian government also helped domestic suppliers grow via policies designed to induce foreign corporations to include the largest possible number of domestically produced parts and larger components in their finished products (Laplane, Sarti, 2004; Wójtowicz, 2012).

Another characteristic of investment in the Brazilian automotive industry is wave pattern cyclicality. The first wave includes the period from 1994 to 2001 with 24.6 billion U.S. dollars in funds invested in Brazil, which was $47.7 \%$ of the total investment value over the analyzed 20-year period (Fig. 4). As Brazil's policies towards the automotive sector changed in 1995, new foreign direct investment began to flow into the country. New foreign automobile manufacturers arrived in Brazil during this time period including Honda (1997), Toyota (1998), Mercedes-Benz (1999), Renault (1999), and PSA Peugeot-Citroën (2001). New investments by Japanese and French manufacturers were part of their strategies to globalize production and acquire new markets (Kilar, Cieluch, 2008; Dorocki, 2010). Most new foreign investors built manufacturing plants outside of the São Paulo metropolitan area. 
Renault built a manufacturing plant in the city of São Jose dos Pinhais near the larger city of Curitiba. Peugeot-Citroën built its plant in the city of Porto Real in the state of Rio de Janeiro. Honda built a plant in the city of Sumare in the interior of the state of São Paulo. Finally, Mitsubishi built its plant in the city of Catalão in the state of Goias (Fig. 5). The arrival of so many new competitors forced existing manufacturers such as Fiat, Ford, General Motors, and Volkswagen to modernize their plants in Brazil and invest in new plants. Hence, the combination of greenfield investments on the part of new and existing automobile manufacturers and brownfield investments consisting of modernization of existing facilities explains the high foreign direct investment during this time period (Wójtowicz, 2008).

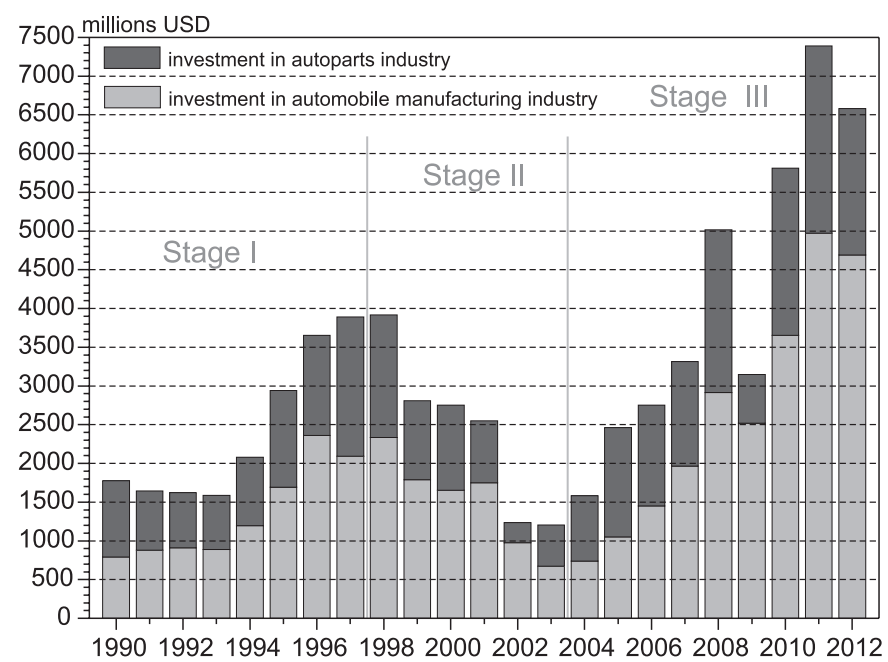

Fig. 4. Foreign direct investment in the Brazilian automobile industry in years 1990-2012

Source: own elaboration based on Anuário da Indústria Automobilística Brasileira 2013, ANFAVEA, 2013

Foreign direct investment decreased significantly between 2002 and 2004 due to the economic crisis in Brazil and declining domestic demand for new vehicles. Production output slowed and stagnation set in. Many new plants could not produce enough vehicles to remain profitable at preset levels. Only $55 \%$ of production capacity at both new and modernized plants was used in 2002 and 2003. This translates into 1.8 million units produced out of 3.1 million units of capacity (Laplane, Sarti, 2004; Wójtowicz, 2008).

An improving economy in Brazil starting in 2004 triggered a resurgence of foreign direct investment, which accounted for $50.9 \%$ of the total investment value for the analyzed 20-year period. The value of foreign direct investment in the period 2005-2012 was about 36.5 billion USD. A second wave of increased foreign direct investment resulted from an economic boom, which generated high demand for new vehicles in Brazil and neighboring countries. Production increased rapidly and capacity was exceeded in years 2007-2008. New investment was needed in order to satisfy growing demand. This was accomplished primarily by expanding existing plants in order to expand production capacity (Wójtowicz, 2012). 
The second wave of foreign direct investment, which begun in 2005 , is expected to continue in the next few years according to statements made by a number of foreign corporations doing business in Brazil. The total investment value expected between 2010 and 2015 is more than 16 billion U.S. dollars. While some foreign corporations have postponed their decision to invest in Brazil, their planned investment amounts may increase if their liquidity crisis is resolved in the near future (Wójtowicz, 2011).

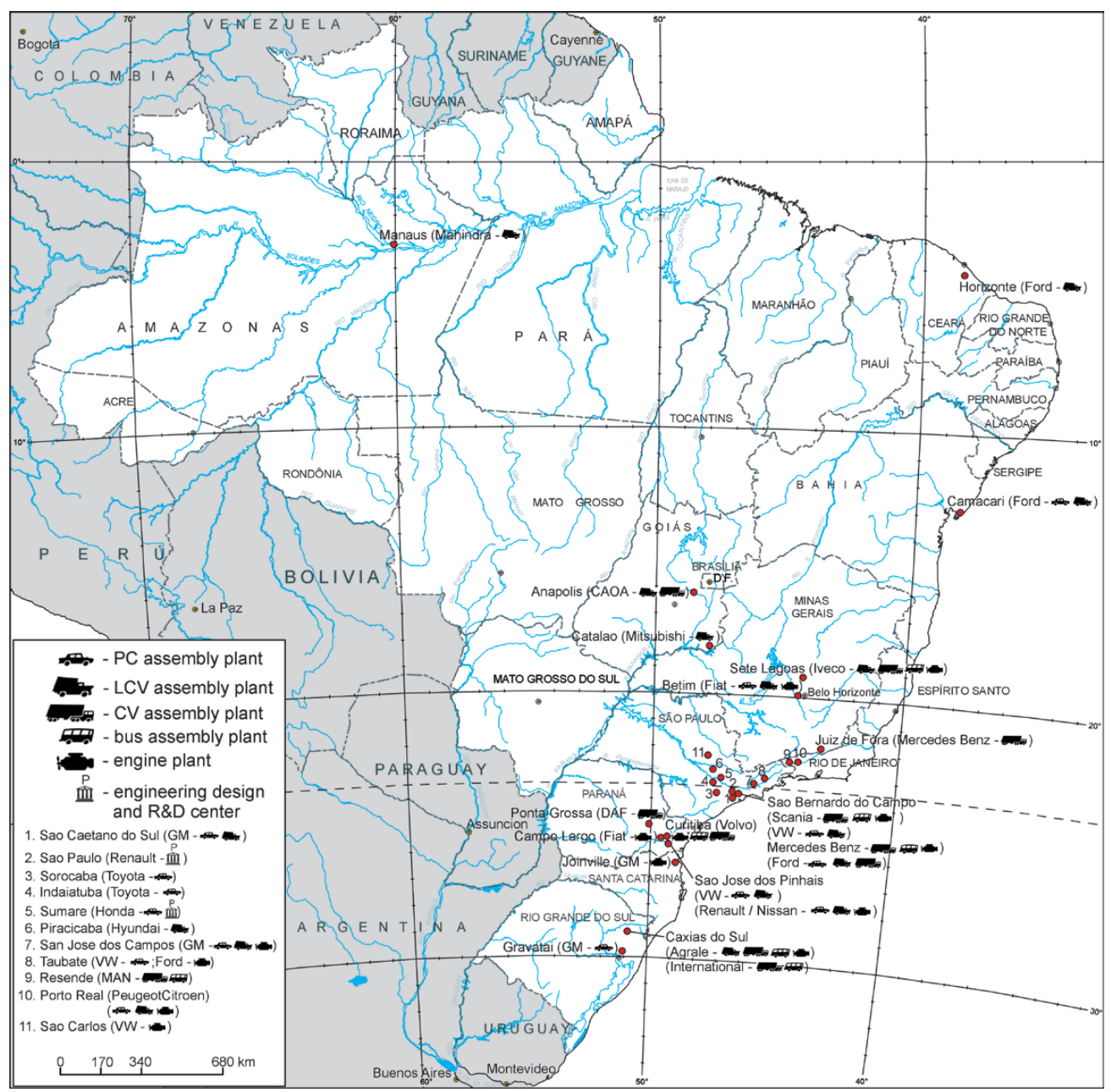

Fig. 5. Major automotive plants and R\&D centers in Brazil

Source: own elaboration based on Anuário da Indústria Automobilistica Brasileira 2013, ANFAVEA, 2013 
MEXICO - GROWING NAFTA AUTOMOTIVE PRODUCTION PLATFORM

The Mexican automotive industry, much like its Brazilian counterpart, consists mainly of divisions of American and European automobile manufacturers enticed to invest in both countries during the postwar industrialization era, known as import substitution industrialization. The first foreign automotive plants in Mexico were opened in the early 1960s by the following large corporations: Ford (Estado de México), General Motors (Toluca), Chrysler (Toluca), Volkswagen (Puebla), Nissan (Cuernavaca). These early markets entrants continue to occupy leading positions in the Mexican automotive market today. Foreign investment in automobile production in Mexico assured access to the Mexican market and virtually eliminated other foreign competitors who chose not to invest directly. Imports were severely limited by very high tariffs, which made automobile production in Mexico in the 1960s a highly advantageous strategy.

However, given little competition within Mexico and isolation from world markets thanks to high tariffs, corporations manufacturing automobiles in Mexico made primarily cheap and old (from a technological standpoint) vehicles. Productivity at plants was not a priority and neither was the production of new and improved models. In spite of this, the automotive sector grew rapidly during Mexico's period of economic growth, especially in years 1978-1982. Mexico's entire economy, along with the automotive industry, entered a period of crisis, which lasted from 1983 to 1987. While domestic sales did decrease significantly, automotive plants in Mexico began to restructure and modernize. New plants were also built at this time (Carrillo, 1991; Miranda, 2007; Wójtowicz, 2012).

The next stage of development and transformation includes the period between 19881993 and is characterized by increased domestic sales and a gradual increase in exports primarily to the United States. This led to an overall increase in automobile manufacturing output in Mexico, which exceeded one million units per year in 1992 (Fig. 6).

The next stage includes the period between 1994-2000 and is characterized by rapid growth in manufacturing output from 1.09 million units to 1.89 million units - an increase of $73.4 \%$. This increase was largely the result of increased exports from 0.78 million units to 1.43 million units - an increase of $83.3 \%$. This stage of development was also characterized by the tendency for the Mexican automotive industry to manufacture mostly for the purpose of exports. This is confirmed by the significant decrease in production for the domestic market, which was suffering from an economic crisis in the mid-1990s. It is noteworthy that the tendency to manufacture for markets abroad was the result of a business strategy adopted by international automotive manufacturers that wished to use Mexico as a production base for the North American market once the country joined NAFTA. Many manufacturers began to limit production for the Mexican market. Most new automobiles sold in Mexico at the time were imported from Brazil, Asia, and Europe, as suggested by the rapid increase in imports from 74,000 units to 402,700 units per year between 1994 and 2000 - an increase of 544.2\% (Fig. 6) (Carrillo, 2004; Covarrubias, 2011; Wójtowicz, 2012). 


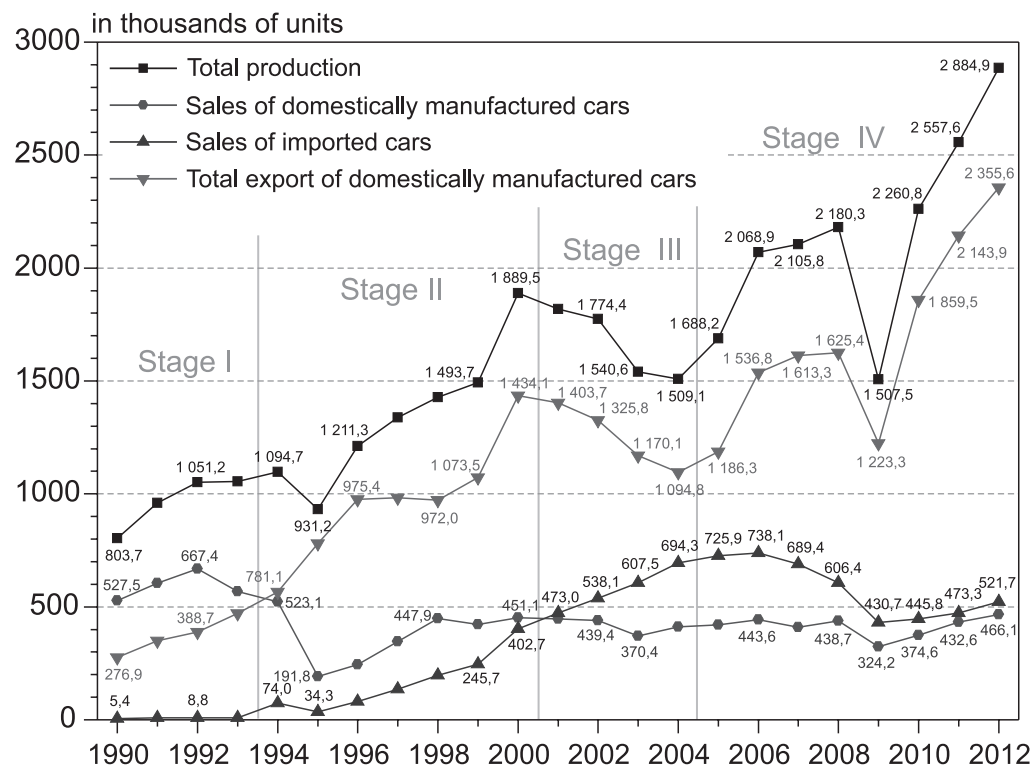

Fig. 6. Mexico - production, sales and exports of automobiles in years 1990-2012

Source: own elaboration based on La industria automotriz en México 2000, 2010, INEGI, AMIA (several years)

The period between 1994 and 2000 was characterized by the transition from production for the Mexican market to production for markets abroad. This was especially true of the three largest American manufacturers - General Motors, Ford, and Chrysler - that wished to take advantage of the trade privileges associated with NAFTA and began to manufacture in Mexico for the purpose of sales in the United States and Canada. This made it possible to enhance their level of competitiveness in light of the increasing threat of Japanese and European imports in the United States and Canada. The shifting of production to Mexico significantly lowered costs, especially labor costs. The so-called Big Three of Detroit began to manufacture in Mexico large and relatively expensive passenger cars, pickups, and SUVs. Most of these vehicles were beyond the financial means of most Mexican consumers (Carrillo, 2004; Wójtowicz, 2012).

Domestic demand in Mexico was satisfied by imports of smaller and cheaper automobiles from plants in Brazil, Asia, and Europe. As previously mentioned, imports skyrocketed from a value of 3.31 billion U.S. dollars to 17.06 billion U.S. dollars in the period between 1994-2000, an increase of more than 500\%. However, the cost of imports was more than offset by revenue from exports, which increased from 8.41 billion U.S. dollars to 28.16 billion U.S. dollars in the same period of time. This helped Mexico's automotive industry to maintain a positive trade balance at more than 11 billion U.S. dollars in years 1999-2000 (Fig. 7). 


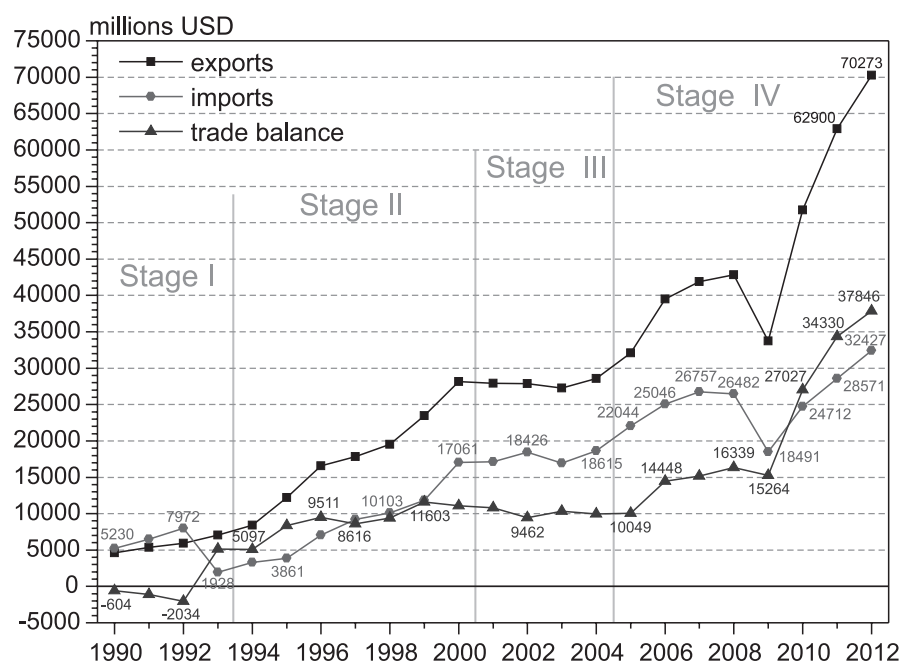

Fig. 7. Mexico: international trade - the automobile industry in years 1990-2012

Source: own elaboration based on La industria automotriz en México 2000, 2010, INEGI, AMIA (several years)

The next stage includes the period between 2001-2004 and is characterized by a decrease in manufacturing output to about 1.5 million units. The decrease was particularly large in the case of vehicles built for export purposes, which was linked to fluctuations in the currency exchange rate as well as economic recession and increased inflation in the United States - both factors limiting demand for new automobiles (Fig. 6). Mexico's automobile trade balance for this time period changed only minimally. This stage was characterized by stagnation of exports at about 28 billion U.S. dollars and a positive trade balance at about 10 billion U.S. dollars (Fig. 7).

The most recent stage of automobile industry development in Mexico began in 2005 and remains current. The only exception was 2009 when the American automotive market suffered a recession and Mexico's automobile production decreased by $28.1 \%$ relative to the year before. The effects of the American crisis proved to be short-lived, and Mexico's production increased in 2010 to more than 2.26 million vehicles - a record number of vehicles produced in Mexico. In addition, Mexico's 2010 automobile exports also exceeded a record level of 51.7 billion U.S. dollars, and its automotive trade balance exceeded 27 billion U.S. dollars. Another output record was reached in 2012 at close to 2.9 million vehicles (Fig. 6). Exports also reached record levels in 2012, exceeding 70 billion U.S. dollars, while Mexico's automotive trade balance stood at more than 37.8 billion U.S. dollars (Fig. 7).

The most recent stage is characterized by significant increases in production, improved labor productivity, introduction of new models, and exports to new markets, which stood at more than 2.35 million vehicles in 2013 (Fig. 6). Mexico's automotive industry managed the 2009 crisis very well and took advantage of the economic recovery in the United States and Canada and rapidly increased exports. However, a correspondingly strong recovery in 
Mexico's domestic market was not observed, although sales of domestically manufactured automobiles were higher in 2012 than in 2008. Finally, sales of imported automobiles remained significantly below 2008 levels (Fig. 6).

Mexico's automotive industry is growing thanks to new investment by global automotive corporations. The output increases and additional exports described above would not be possible without increasing manufacturing capacity and industrial upgrading, both of which are made possible by foreign direct investment. Mexico received more than 36 billion U.S. dollars in foreign direct investment between 1990 and 2012. Unlike in Brazil, most of the funds were invested in the creation of manufacturing jobs in the automotive parts sector, which is a more labor-intensive sector. Foreign direct investment data for years 1990-2012 indicate that only 7.5 billion U.S. dollars $(28.9 \%)$ out of 26 billion U.S. dollars were invested in the production and assembly of vehicles, while 18.5 billion U.S. dollars (71.1\%) were invested in the production of automotive parts and accessories (Fig. 8).

The investment profile above suggests that Mexico is treated differently by international automotive corporations - it is a place to manufacture parts and larger components that will be assembled in the United States and Canada. This is especially true of the Big Three of Detroit, which have not shifted complete production to Mexico, but wish to lower labor costs in the labor-intensive automotive parts production sector. This allows American automobile manufacturers to better compete with their more efficient Japanese counterparts, which are becoming increasingly strong in the domestic market in the United States (Carrillo, 2004; Covarrubias, 2011).

The influx of foreign direct investment (FDI) to Mexico accelerated in the period between 1992-1997, with 22.8\% (more than 8.2 billion U.S. dollars) of total FDI in the studied period. This increase can be linked to Mexico's membership in NAFTA starting in 1994 and the related ease of access to American and Canadian markets by companies manufacturing in Mexico. The U.S. automotive industry was particularly interested in shifting some production to Mexico, which led to the investment of more than 5.5 billion U.S. dollars in years 1992-1996. The inclusion of Mexico in the American and Canadian free trade zone was very advantageous to American corporations seeking to lower labor costs associated with labor-intensive manufacturing and become more competitive relative to more efficient Japanese competitors making headway in the American and Canadian markets (Carrillo, 2000; Wójtowicz, 2012).

In 1998 Mexico noted an abrupt decrease in foreign direct investment in the automotive industry due to a global economic crisis affecting the so-called Asian Tigers as well as emerging economies. Global corporations elected not to take bigger risks in the global marketplace at the time. However, the year that followed was very successful for Mexico with an inflow of more than 2.2. billion U.S. dollars, of which 1.38 billion U.S. dollars were invested in plants making automobiles. The following few years were characterized by gradual decreases in direct foreign investment in Mexico. Investment in automobile manufacturing was strongly affected. The next acceleration in investment came in 2004 and lasted until 2007, with an influx of 8.5 billion U.S. dollars or $23.6 \%$ of total foreign direct investment in Mexico's automotive industry during the studied period. Only 21.2\% (1.8 billion U.S. 
dollars) of this amount was invested in the production of automobiles, while $78.8 \%(6.7$ billion U.S. dollars) was invested in the production of parts. This confirms Mexico's specialization as a center of automobile parts manufacturing (Fig. 8).

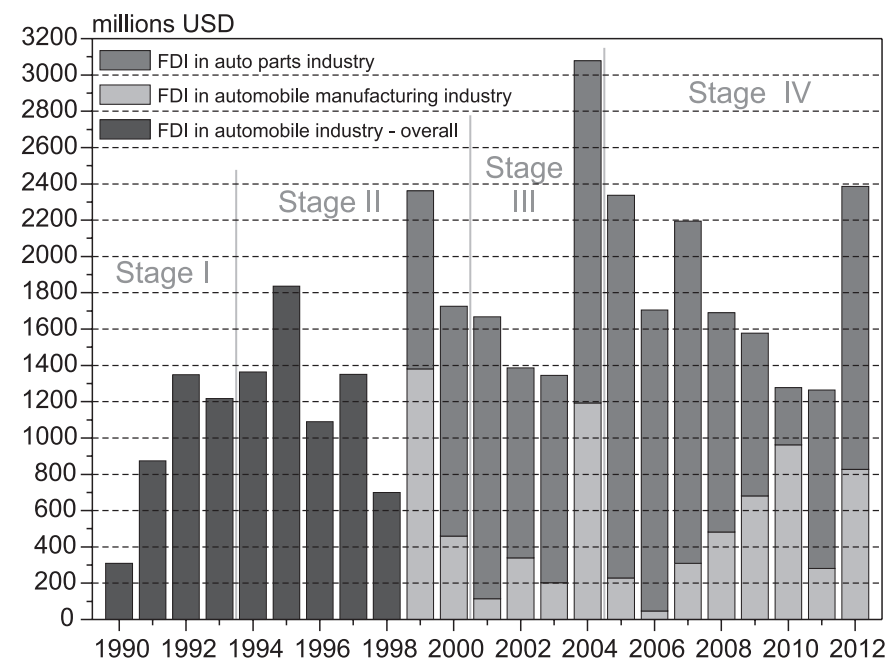

Fig. 8. Foreign direct investment in the Mexican automobile industry in years 1990-2012

Source: own elaboration based on La industria automotriz en México 2000, 2010, INEGI, AMIA (several years)

American automobile manufacturers were once again the leading investors in Mexico in the period of 2003-2009 with a declared intention of investing more than 8.1 billion U.S. dollars, which was equivalent to $69.9 \%$ of all planned automobile industry investment in Mexico in this period (Wójtowicz, 2012). Most planned investments are announced a year before realization. For example, most of the 2.3 billion U.S. dollars in investment funds announced in 2003 was actually spent in 2004. This means that the value of investment in 2004 reached close to 2.7 billion U.S. dollars, of which almost 1.2 billion U.S. dollars were invested in manufacturing of automobiles. This trend was set to repeat in 2006 and 2008 when automobile manufacturers announced major investment projects, but the global financial crisis of 2008 halted many of these projects due to economic problems in the United States. American direct investment in Mexico's automotive sector helped to lift total FDI levels close to 2.4 billion U.S. dollars in 2012 (Fig. 8).

Foreign direct investment in the automobile industry has created a unique geography of automobile manufacturing in Mexico. The largest number of automobile plants are found in the following states in the central part of the country: Mexico (Toluca, Cuautitlán, Tultitlán, Santiago Tianguistengo, San Martin Tepetlixpan), Puebla (Puebla, San José de Chiapa), Guanajuato (Guanajuato, Silao, Salamanca, Celaya), Jalisco (El Salto), Querétaro, Morelos, San Luis Potosi, Aguascalientes. The next cluster of automobile producing states includes northern border states such as Nuevo León (Escobedo, Garcia) and Coahuila (Saltillo, 


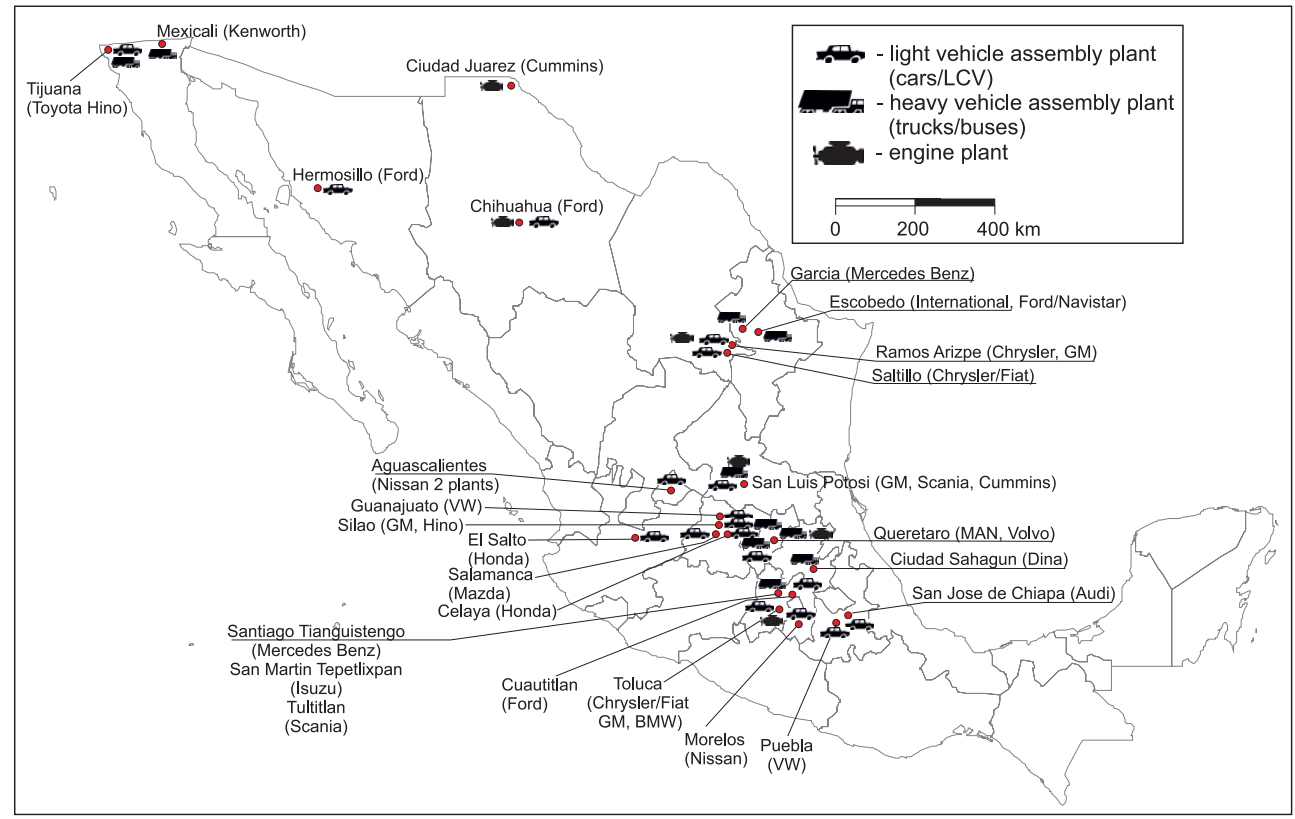

Fig. 9. Major automotive plants in Mexico

Source: own elaboration based on The Automotive Industry, 2013

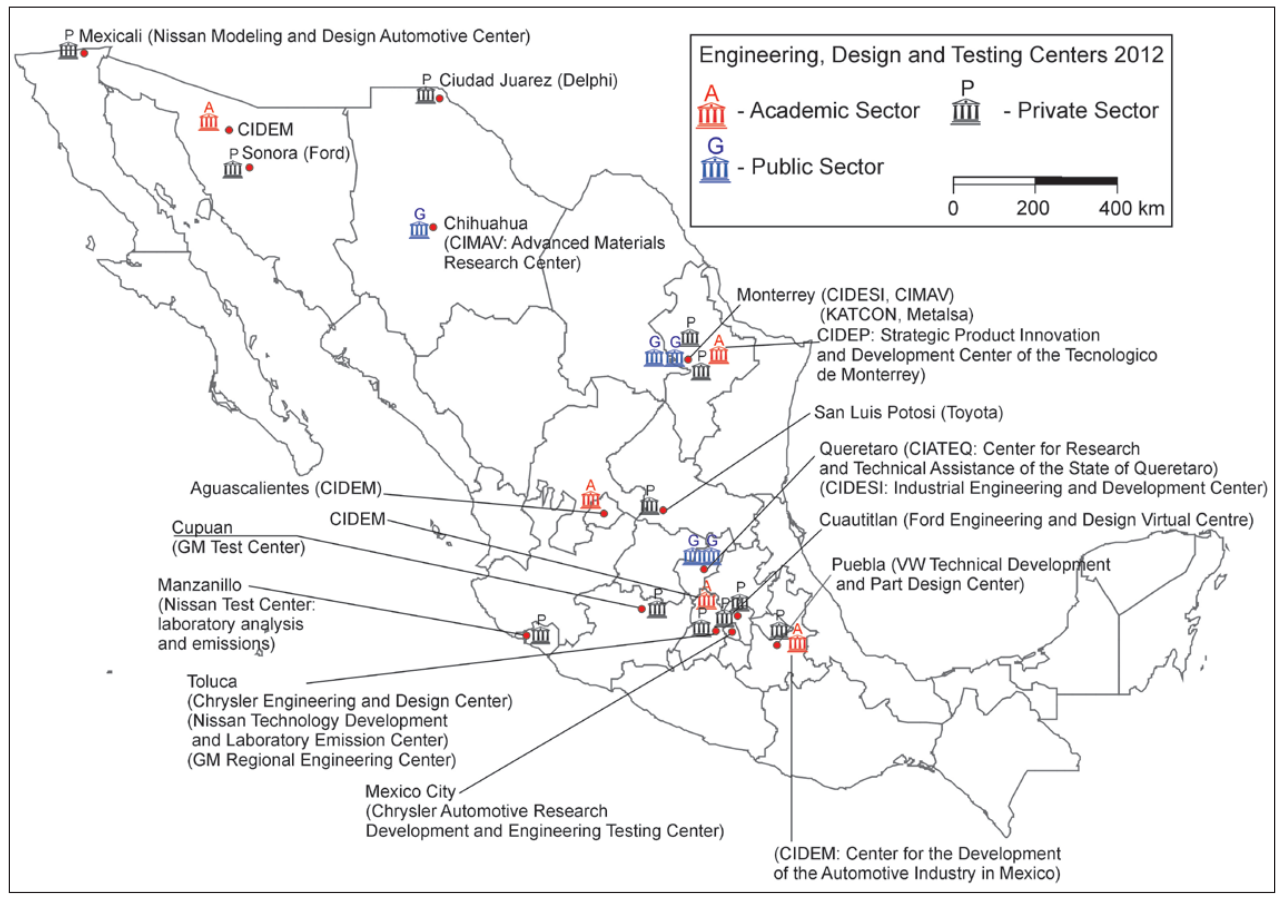

Fig. 10. Major elaboration, design, testing, and R\&D centers in Mexico

Source: own elaboration based on The Automotive Industry, 2013 
Ramoz Arizpe). Both Mexican states border the United States. The largest city in the region is Monterrey. While it does not possess any manufacturing facilities, it is a key center of learning and research based on schools and universities that educate future automotive employees. Monterrey also possesses some institutions focused on research and development (Figs. 9 and 10).

The following cities in northern Mexico have become centers of automotive production in recent years: Chihuahua, Ciudad Juarez, Hermosillo, Mexicali, Tijuana. Another key economic player in Mexican border states is the maquiladora - a plant operating within a special economic zone along the American - Mexican border. Maquiladoras operate by importing mainly U.S. raw materials and other equipment without paying Mexican tariffs, and use them to manufacture finished goods, which are then sold back to the United States and Canada. Many maquiladoras also manufacture automotive parts and accessories (Carrilo, 1997; Carrillo et al., 2005).

The emergence of R\&D centers in Mexico is one of the signs of modernization and industrial upgrading of the country's automotive sector. Other signs include the emergence of vehicle design and test facilities, component design and test facilities, and materials design and test facilities. Three types of R\&D centers have been identified in Mexico:

- Private centers associated with automotive corporations such as GM, Chrysler, and Delphi;

- Public centers associated with national and state-level research institutions supporting the development of industry and pursuing research on new materials;

- Academic centers associated with universities and related R\&D institutions (CIDEM, CIDEP).

The largest number of $R \& D$ centers are found in cities in central Mexico including Mexico City, Toluca, Puebla, and Cuautitlan. Other key centers of R\&D activity include the city of Monterrey and the northern border cities of Ciudad Juarez, Mexicali, Sonora, and Chihuahua (Fig. 10). The increasing number of R\&D centers with capital not limited to that of foreign corporations, but including that of federal government institutions, state institutions, and universities suggests that the automotive industry in Mexico is becoming increasingly embedded in the nation's economy.

\section{Central Europe - THE NEW AutOMOtive PROdUCTION PlATFORM} FOR THE ENLARGED EU

Central Europe abandoned its centrally planned economic model in 1989 along with its special trade zone known as the Council for Mutual Economic Assistance (CMEA). This was followed by the collapse of the Soviet Union and the dissolution of economic ties between former communist nations in the region. Central Europe needed a new business strategy in the context of its new political and economic climate (Havas, 2000; van Tulder, 2004; Pavlínek, 2008). The region did have an automotive industry since the early $20^{\text {th }}$ century; 
however, its automotive industry was relatively inefficient, low on technology, and low on vehicle quality. Its global significance was also small - only $5 \%$ of global passenger car production originated in Central Europe in the early 1990s (van Tulder, 2004). Total automobile production in the six analyzed countries of Central Europe did not exceed one million units per year in the first half of the 1990s (0.73 million in 1990 to 0.86 million in 1995) (Pavlinek, 2008). Production did accelerate in the second half of the 1990 s to more than 1.5 million units in the year 2000 (Fig. 11).

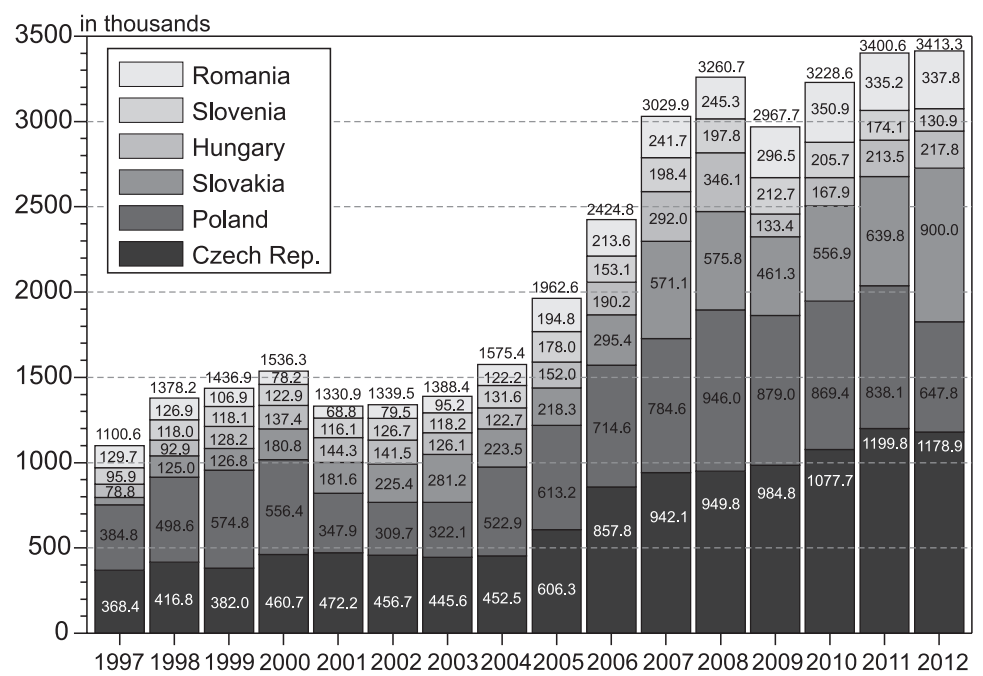

Fig. 11. General trends in automotive production in Central Europe in years 1997-2012

Source: own elaboration based on OICA, World Motor Vehicle Production by Country and Type (several years)

The growth in production suggests that the sector has made the transition from planned economy to market economy and is able to compete outside of Central Europe. This transition occurred mainly via industrial restructuring, which was a common change mechanism during the region's transition from centrally planned to market economy (Rachwał, 2003, 2006a, 2006b). An additional and vital step in the process of economic transformation was the influx of foreign direct investment from global automotive corporations. The largest stream of investment affected the production of passenger cars. According to P. Pavlinek (2008), more than 20.2 billion U.S. dollars were invested by foreign automotive corporations in Central Europe between 1990 and 2007. The largest percentage of the funds were invested in the Czech Republic (7.5 bln USD). Poland was second at 3.99 bln USD and Slovakia was third at 3.35 bln USD. The next three investment choices were Romania (2.45 bln USD), Hungary (2.42 bln USD), and Slovenia (0.5 bln USD) (Pavlinek, 2008).

International automotive corporations pursued several different investment strategies in Central Europe largely depending on their global standing and situation in the home market. Rob van Tulder (2004: 79) divides automotive corporations investing in Central Europe into 
three groups: (1) frontrunners, (2) latecomers, (3) peripheral players. The first group includes firms entering the Central European market in the early 1990s and investing primarily in passenger car production: Volkswagen, Fiat, Renault, Opel. Some Group One companies invested in the region due to longstanding commercial linkages. For example, Fiat had collaborated with Polish firms since the 1960s, and Renault had collaborated with the Slovenian IMV company since 1973.

Most foreign frontrunners invested in Central Europe by acquiring existing plants brownfield investments. This was the case with Volkswagen's acquisition of Škoda and BAZ in Bratislava (Slovakia) in 1991. Fiat purchased FSM Bielsko-Biała (Poland) in 1992. Renault purchased IMV Novo Mesto (Slovenia) in 1993 and Dacia in Romania in 1999 (Havas, 2000; Pavlinek, 2002; van Tulder, 2004). The Opel Company, a division of General Motors, acquired Wartburg in the former East Germany. Opel then decided to pursue greenfield investments in Szengotthard in Hungary (1991) and Gliwice in Poland (1995). Opel's plant in Gliwice helped spark development in the automotive sector in Silesia and generated significant multiplier effects throughout the region (Rachwał, Wiedermann, 2008).

The automotive latecomers in Central Europe are PSA, Ford, and Toyota, whose initial view of the region was not that of a manufacturing base for Western Europe. Instead, the three companies saw Central Europe simply as a market for their vehicles and not a place to acquire existing automotive manufacturers. Ford attempted to start vehicle assembly in Poland (SKD), but backed out in 2000. In 2007 Ford acquired the former Oltcit plant in Craiova (Romania). The plant had been sold previously to Daewoo (1994), but the company went bankrupt in 2000. PSA did not bid high enough to acquire any plants during the privatization era of the early 1990s. The company decided to build a plant in Kolin (Czech Republic) in conjunction with Toyota in 2001. PSA decided to build a second plant in Trnava (Slovakia) in 2003 (van Tulder, 2004; Pavlinek, 2008; Pavlinek et al., 2009).

The last group includes smaller players in the global and European automotive markets that chose to invest in Central Europe expecting to encounter growing demand in the region and easier access to Western European markets. These smaller companies include Daewoo, Suzuki, Kia, and Hyundai. The first company to enter Central Europe was Suzuki, which built a plant in 1990 in Esztergom (Hungary) to manufacture subcompact cars. Next, Daewoo set out with an ambitious plan to acquire Automobile Craiova (Romania) in 1994 and FSO Warsaw (Poland) in 1995. Its global plans turned out to be too ambitious and the company went bankrupt in 2000. General Motors acquired some of Daewoo's plants, but not including those in Central Europe. When it became apparent that Central Europe would join the European Union, other Korean automotive firms made the decision to enter the region. The Kia Company built a plant in Žilina (Slovakia) in 2004 and Hyundai built a plant in Nošovice (Czech Republic) in 2006 (Pavlinek, 2008; Pavlinek et al., 2009; Dorocki, 2010; Lizak, 2009, 2011).

Investments made directly by international automotive corporations significantly helped Central Europe to modernize and integrate its automotive industry with global and regional business networks. Manufacturing output increased substantially - exceeding 3.4 million units in 2012. The Czech Republic is the current regional leader in automotive manufacturing with close to 1.2 million units produced. Slovakia produces 0.9 million units. On the other 
hand, production in Poland decreased between 2008 and 2012 from 0.95 million units to 0.65 million units - a decrease of $31.5 \%$ (Fig. 11).

According to the European Automobile Manufacturers Association, sixteen passenger car plants, seventeen commercial vehicle plants, and fourteen engine plants were operating in Central Europe in 2013 (Tab. 1).

Tab.1. Number of assembly and engine plants in Central Europe by country in 2013

\begin{tabular}{|c|c|c|c|c|c|c|}
\hline \multirow{2}{*}{ Country } & \multicolumn{5}{|c|}{ Product } & \multirow{2}{*}{ Brand } \\
\hline & engine & $\mathrm{PC}$ & $\mathrm{LCV}$ & $\mathrm{CV}$ & Bus & \\
\hline Czech Republic & 3 & 5 & - & 2 & 3 & $\begin{array}{l}\text { Škoda, Toyota, Peugeot, Citroën, } \\
\text { Tatra, Avia, Sor, Hyundai, } \\
\text { Tedom, Irisbus }\end{array}$ \\
\hline Hungary & 2 & 3 & - & - & 1 & $\begin{array}{l}\text { Suzuki, Opel, Fiat, Audi, Nabi, } \\
\text { Mercedes-Benz }\end{array}$ \\
\hline Poland & 5 & 2 & 1 & 2 & 6 & $\begin{array}{l}\text { Fiat, Opel, VW, Solaris, MAN, } \\
\text { Scania, Volvo, Jelcz, Solbus }\end{array}$ \\
\hline Romania & 3 & 2 & - & 1 & 1 & Dacia, Ford, Roman \\
\hline Slovakia & 1 & 3 & - & - & - & $\begin{array}{l}\text { VW, Audi, Škoda, Peugeot, } \\
\text { Citroën, Kia }\end{array}$ \\
\hline Slovenia & - & 1 & - & - & - & Renault \\
\hline Total & 14 & 16 & 1 & 5 & 11 & - \\
\hline
\end{tabular}

Source: own elaboration based on European Automobile Manufacturers Association - ACEA, 2013

The region's automotive industry is located primarily in southwestern Poland, northern Czech Republic, northwestern Slovakia, and Hungary (Rachwał, Wiedermann, 2008; Pavlinek et al., 2009; Gwosdz, Micek, 2010; Lizak, 2011) - Fig. 12.

International automotive corporations investing in Central Europe since the 1990s have pursued two basic business strategies. The first strategy consists of the mass production of small cars for the local market and for export to Western Europe. This first strategy takes advantage of lower labor costs in Central Europe, which translates into lower prices at car dealerships. This is especially important in the small car segment. At the same time, demand for small cars was the greatest in Central Europe due to the much lower purchasing power of its inhabitants. In order to realize this strategy, automotive companies needed to create a stronger network of local suppliers. The end result was greater embeddedness of foreign automotive companies operating in Central Europe. Greater embeddedness leads to more industrial upgrading, which was beneficial for the region as a whole. Plants in Central Europe upgraded their technological infrastructure in order to meet the requirements set by global automotive corporations (Pavlinek, 2002; Pavlinek et al., 2009).

The strategy of embeddedness also generated meaningful multiplier effects in the local economies of Central Europe. Automobile manufacturing plants owned by foreign corporations were also able to attract large suppliers to Central Europe, which produced significant multiplier effects (Rachwał, Wiedermann, 2008; Domański, Gwosdz, 2009). 


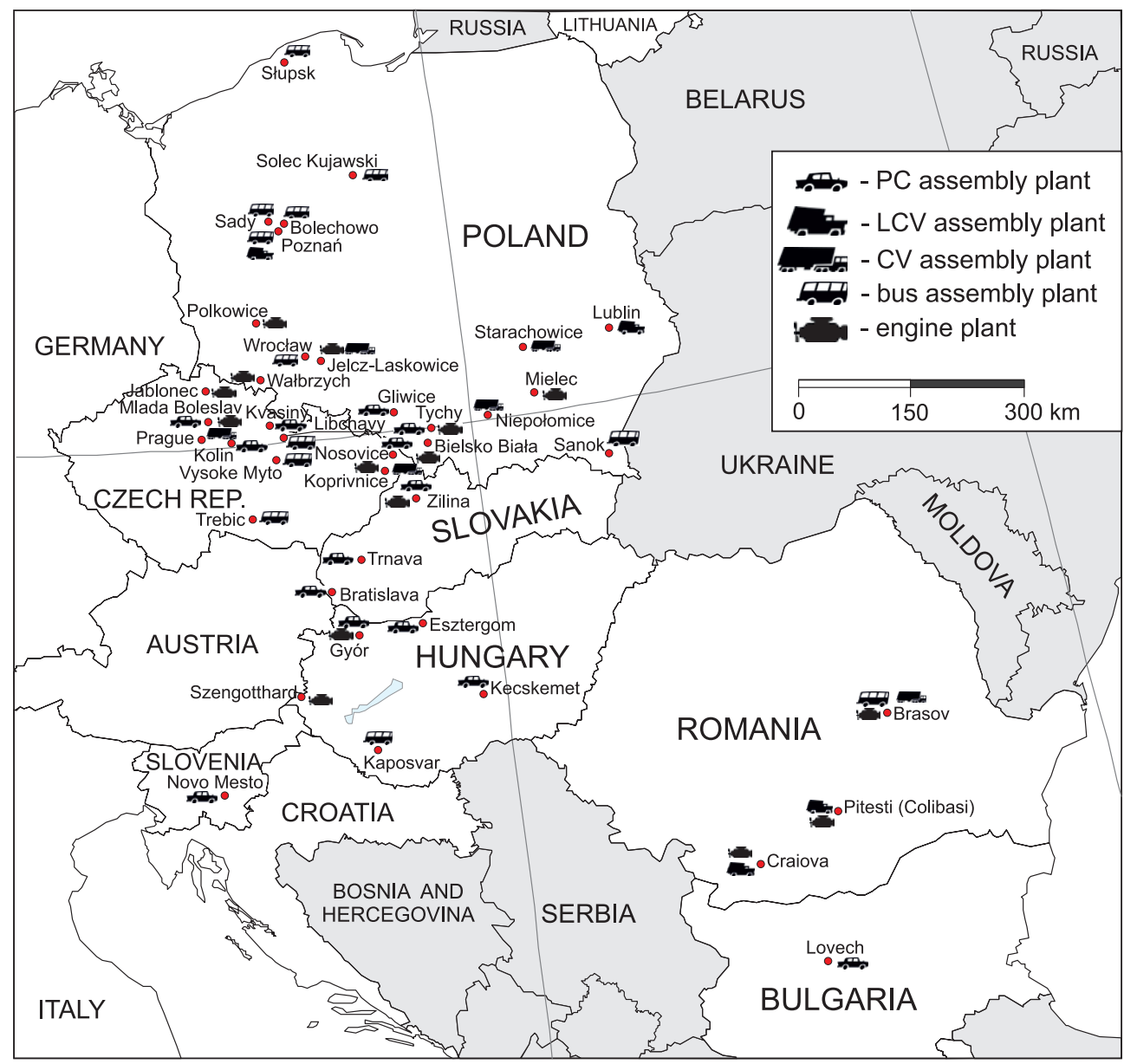

Fig. 12. Major automotive plants in Central Europe

Source: own elaboration based on European Automobile Manufacturers Association (ACEA), and Pavlínek, Domanski, Guzik, 2009: 47

The second strategy consisted of low-volume production of specialized automobiles such as sports cars designed for export to more affluent markets in Western Europe. Examples of this include the Audi plant in Gyor and Opel plant in Szentgotthard in Hungary and the Volkswagen plant in Bratislava in Slovakia. Cars were assembled using parts imported from Western Europe, with little input from local suppliers. The main point of this investment was to take advantage of lower labor costs in Central Europe and produce cars using a relatively highly skilled labor force. This type of investment strongly resembled the maquiladoras of the border area of Mexico and the United States (Ellingstad, 1997; Pavlinek, 2002).

The direct investment strategies described above were able to produce higher automobile exports, most of which were destined for Western Europe (old 15 EU member states). The largest exporter of automobiles in Central Europe is the Czech Republic, whose automobile 
exports increased from 2.2 billion euro in 1999 to 12.4 billion euro in 2012. Most exported vehicles are still sold in the old 15 member states of the European Union, although the proportion of vehicles sold there is decreasing. In 1999 exports to the old 15 EU member states accounted for $76.1 \%$ of all vehicles exported from Central Europe. That share decreased to $66.7 \%$ by 2012 due to exports primarily within Central Europe itself. The second largest exporter of automobiles in 2012 was Slovakia at 10.5 billion euro. Poland was third at 8.3 billion euro, which was $13.5 \%$ less than its exports in 2008 . About $90 \%$ of automobile exports from Poland and Slovakia were headed to the old 15 member states of the European Union in 1999. By 2012 that share decreased to $60.1 \%$ for Slovakia and 73.2\% for Poland. Given Poland's stronger dependence on automobile exports to Western Europe, its automotive industry suffered a greater decline during the global financial crisis starting in 2008 (Fig. 13).

The global financial crisis of 2008 also affected automobile exports from Hungary and Slovenia. No corresponding effect was observed in Romania, which actually experienced rapid growth from 0.8 billion euro in 2007 to 2.7 billion euro in 2012 . This can be explained by the successful restructuring of Romania's Dacia Company by its new owner Renault, which had purchased Dacia in 1999 and began to introduce new low-cost models later than other companies. These new smaller and cheaper models became quite popular in time of economic crisis. Another source of increased exports by Romania was the plant in Craiova, which had been acquired in 2007 by Ford. Both the Renault and Ford plants helped Romanian-built cars regain a degree of popularity in Western Europe. The share of cars made in Romania and exported to the old 15 members states of the European Union increased from $42.1 \%$ in 2006 to $80.7 \%$ in 2009 , while decreasing to $60.1 \%$ in 2012 (Fig. 13).

The global financial crisis of 2008 also negatively impacted the imports of automobiles by Central European countries. This was especially true of Hungary, Romania, Slovenia, and Poland. On the other hand, Slovakia and the Czech Republic imported relatively few cars during the studied period in general; therefore, the decline in imports was relatively minor. In summary, all countries in Central Europe have enjoyed a positive automobile trade balance in recent years, with the leaders being the Czech Republic (9.7 bln euro) and Slovakia (8.9 bln euro) (see Fig. 13).

The situation is different in the parts and accessories manufacturing sector. Exports in this sector in 2012 were highest for Poland (6.9 bln euro) and the Czech Republic (8.1 bln euro). Exports in this sector from Slovakia, Hungary, and Romania were about 50\% smaller. Finally, Slovenia's parts and accessories exports did not exceed 0.6 bln euro in 2012 (Fig. 14).

Virtually all Central European countries are increasing their exports of automobile parts. The global financial crisis of 2008 only managed to put a dent in exports in 2009 and 2010. More recent years are once again characterized by growth in parts exports, which now exceed pre-crisis levels. Central Europe can be divided into two groups of countries based on trade balance in the parts sector: (1) countries with a positive trade balance - the Czech Republic, Hungary, Poland, Romania, (2) countries with a negative trade balance - Slovenia, Slovakia. The latter two have experienced a negative trade balance in the parts sector throughout the studied period. This can be explained by lower levels of embeddedness of foreign automobile manufacturers operating in Slovenia and Slovakia and a relatively small number of 
subcontractors demanding the importing of needed parts and components. It is noteworthy that more than $90 \%$ of parts imports by Slovenia and Slovakia originated in the old 15 member states of the European Union in the late 1990s. However, parts imports declined to $51.1 \%$ by 2012 in the case of Slovakia and $63.7 \%$ in the case of Slovenia. This suggests the emergence of regional linkages in the case of both countries. On the other hand, automotive parts exports by net parts exporters such as the Czech Republic, Hungary, Poland, and Romania are increasingly less focused on the old 15 member states of the European Union and more focused on other countries within Central Europe. For example, the value of parts exports by the Czech Republic to the old 15 member states declined from $82 \%$ in 2003 to $65.7 \%$ in 2012 . For Poland, the decline was from $84.1 \%$ in 2003 to $68.3 \%$ in 2012 . Finally, for Romania the decline was from $90.4 \%$ in 2003 to $50.3 \%$ in 2012 (Fig. 14).

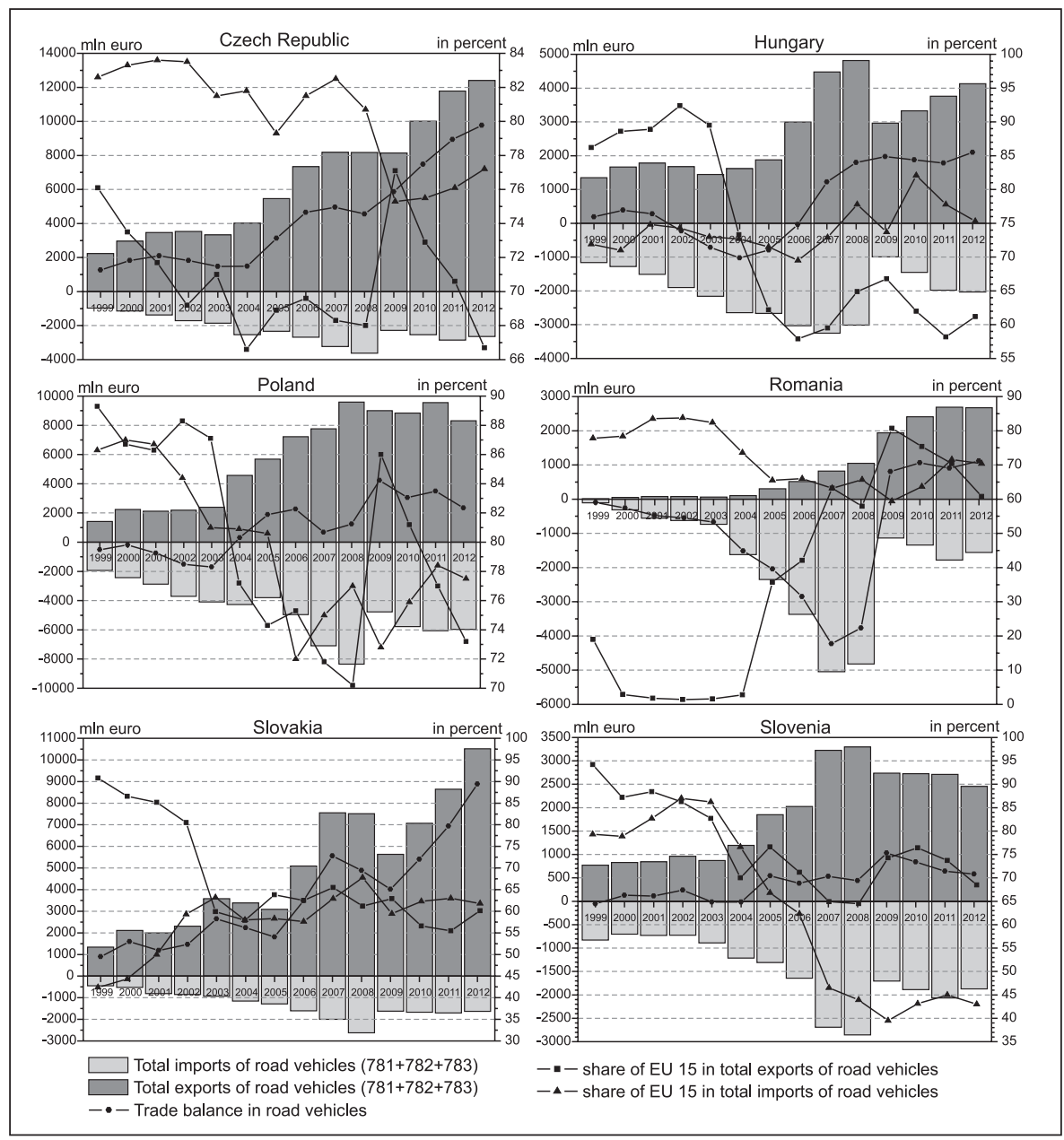

Fig. 13. Trade balance in road vehicles in Central European countries in years 1999-2012

Source: own elaboration based on Eurostat, International trade detailed data, 2013 


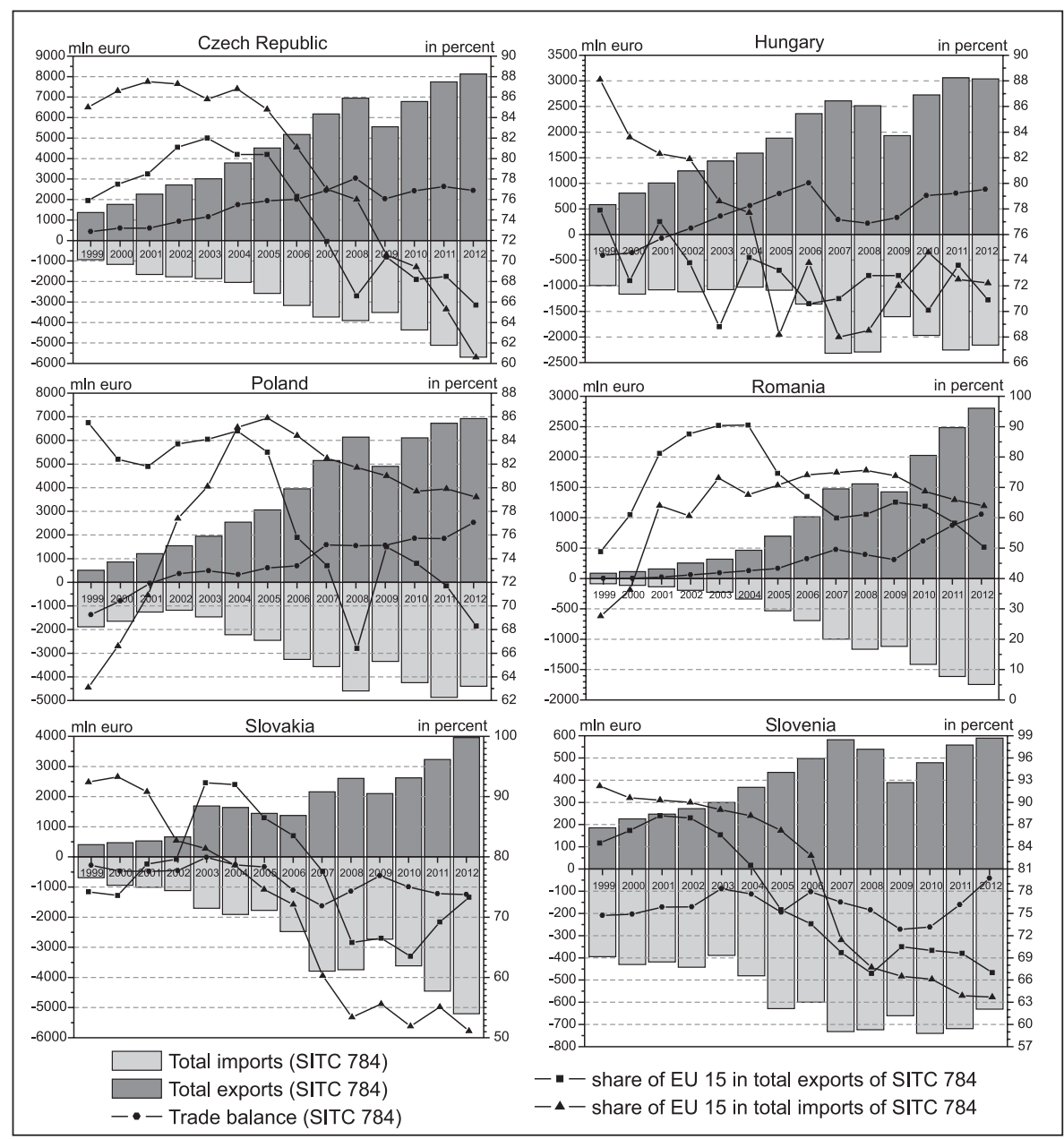

Fig. 14. Trade balance in vehicle parts and accessories in Central Europe in years 1999-2012 Source: own elaboration based on Eurostat, International trade detailed data, 2013

\section{CONCLusions}

Research has shown that the automotive industry in Brazil, Mexico, and Central Europe has experienced a fundamental transformation and modernization, which has helped the sector to adapt to global market conditions. The automotive sectors in analyzed countries had to adapt to global competition standards in terms of labor productivity, technological quality, and external appearance of vehicles. Two key drivers of change have been globalization, 
which forces companies to adopt global production strategies, and regional integration via organizations such as NAFTA, MERCOSUR, and the European Union. Local factors and domestic market size have also played a key role in the development of each region's automotive industry. For example, modernization processes in Mexico proceeded much more quickly than in Brazil due to its focus on production for the American and Canadian markets. In addition, Brazil's government and labor unions tended to block the modernization or liquidation of the least productive plants via various policies and other actions (Laplane, Sarti, 1997; Anner, 2003). The domestic market in each region is largely shaped by local economic conditions, income patterns, and the stability of interest rates. In the case of Mexico and Central Europe, imports of used automobiles from the United States, Canada, and Western Europe have reduced demand for new automobiles.

In light of the dependence of Mexico on the American automobile market and that of Central Europe on the Western European automobile market, both regions have tended to face more fluctuations in automotive production than Brazil in the studied 20-year period. In addition, given Mexico's status largely as a parts manufacturing base for American corporations doing business in the United States and Canada, the country has enjoyed much less foreign direct investment in vehicle assembly plants than Brazil. Most Mexican automotive plants are focused on manufacturing automotive parts, especially labor-intensive parts. A similar tendency can be observed in Central Europe, which is dominated by Western European manufacturers.

The situation in Brazil was much more balanced and dominated by investment in vehicle assembly for the domestic market, which also forced suppliers to invest in their businesses. In light of the Brazilian automotive industry's orientation towards the domestic market and only some exports, mainly to other MERCOSUR countries, the global financial crisis of 2008 did not impact the country substantially. While Brazilian automotive exports declined more than $30 \%$ in 2009 , domestic automotive sales actually increased by $9 \%$ largely thanks to government incentives to purchase automobiles including tax breaks and preferential interest rates.

The global financial crisis of 2008 strongly affected Mexico's automotive industry due to its strong orientation towards exports to the United States and Canada. Mexico had exported three out of four cars to the United States and Canada in the years leading up to the crisis. Hence, production for both markets declined significantly once the crisis set in. A similar situation was observed in Central Europe. Given its strong orientation towards the Western European market, where production declined close to 9\% in years 2008-2009 due to the global financial crisis, exports to Western Europe also declined. In addition, domestic automotive markets both in Mexico and Central Europe experienced recessions at the same time. However, both recessions were offset somewhat by increased exports and production soon returned to pre-crisis levels. The domestic automotive market in Mexico and Central Europe remains stagnant.

According to statements made by global automotive corporations, Brazil's automotive industry is set to enter a period of accelerated development characterized by new investment, new plant construction, and existing plant expansion. This new growth is designed to meet demand for new automobiles both in Brazil and in neighbouring countries. Finally, growth 
in the automotive industry in Central Europe depends largely on the state of the economy in Western Europe, and growth in the automotive industry in Mexico depends largely on the state of the economy in the United States and Canada.

\section{References}

AMIA (2009, 2010). AMIA-Boletin de Prensa, Asociacion Mexicana de la Industria Automotriz AMIA, Mexico. Retrieved from http://www.amia.com.mx/prensa.

ANFAVEA (2010, 2013). ANFAVEA - Tabelas Estatisticas, Associaçăo Nacional dos Fabricantes de Veículos Automotores - ANFAVEA, Săo Paulo. Retrieved from http://www.anfavea.com.br/ tabelas.html.

Anner, M. (2003). Industrial Structure, the State, and Ideology. Shaping Labor Transnationalism in the Brazilian Auto Industry. Social Science History, 27(4), 603-634.

Carrillo, J. (1991). Restructuración en la industria automotriz en México. Estudios Sociológicos, 9(27), 483-525.

Carrillo, J. (1997). Maquiladoras automotrices en México: Clusters y competencias de alto nivel. In: M. Novick, M. Gallart (eds.), Competitividad, redes productivas y competencias laborales. Montevideo: OIT/CINTERFORD/Red Educación y Trabajo, 193-234.

Carrillo, J. (2000) The integration of the Mexican Automobile Industry to the USA: between polices and corporate strategies. Actes du GERPISA, 28, 55-77.

Carrillo, J. (2004). NAFTA: The Process of Regional Integration of Motor Vehicle Production. In: J. Carrillo, Y. Lung, R. van Tulder (eds.), Cars, Carriers of Regionalism? Houndmills-New York: Palgrave Macmillan, 104-117.

Carrillo, J., Hualde, A., Quintero, C. (2005). Maquiladoras en México. Breve recorrido histórico. Comercio Exterior, 55(1), 30-42.

Covarrubias, A.V. (2011). The Mexican Auto Industry: From Crisis to Greater Region-centric Influence. Norteamerica, 6(2), 115-155.

Domański, B., Gwosdz, K. (2009). Toward a More Embedded Production System? Automotive Supply Networks and Localized Capabilities in Poland. Growth and Change, 40(3), 452-482.

Dorocki, S. (2010). Współczesne procesy internacjonalizacji produkcji i delokalizacji przemysłu samochodowego Francji. Prace Komisji Geografii Przemystu Polskiego Towarzystwa Geograficznego, $16,125-136$.

Ellingstad, M. (1997). The maguiladora syndrome: Central European prospects. Europe - Asia Studies, $49(1), 7-21$.

Eurostat (2013). International trade detailed data, EU-27 trade since 1988 by SITC, 1999-2012. Retrieved from http://epp.eurostat.ec.europa.eu/portal/page/portal/statistics/search_database.

Freyssenet, M., Lung, Y. (2004). Multinational Carmakers' Regional Strategies. In: J. Carrillo, Y. Lung, R. van Tulder(eds.), Cars, Carriers of Regionalism? Houndmills-New York: Palgrave Macmillan, $42-54$.

Gwosdz, K., Micek, G. (2010). Spatial agglomerations in the Polish automotive industry. Przeglad Geograficzny, 82(2), 159-190.

Kilar, W., Cieluch, M. (2008). Kształtowanie się i organizacja przestrzenna korporacji ponadnarodowej Honda. Prace Komisji Geografii Przemystu Polskiego Towarzystwa Geograficznego, 10, 188-203.

Klimkowska, R. (2011). Zmiany gospodarcze i społeczne wywołane globalizacją a strategie dostosowawcze koncernów samochodowych. Zeszyty Naukowe. Uniwersytet Ekonomiczny w Poznaniu, $171,216-224$. 
Laplane, M.F., Sarti, F. (1997). The Restructuring of the Brazilian Automobile Industry in the Nineties'. Actes du GERPISA, 20, 31-49.

Laplane, M.F., Sarti, F. (2004). MERCOSUR: Integration between Governments and Producers and the Sustainability of the Regional Automobile Industry. In: J. Carrillo, Y. Lung, R. van Tulder (eds.), Cars, Carriers of Regionalism? Houndmills-New York: Palgrave Macmillan, 121-138.

Lizak, P. (2009). Kształtowanie się przemysłu samochodów osobowych w krajach Europy Środkowej w latach 1997-2007. Prace Komisji Geografii Przemystu Polskiego Towarzystwa Geograficznego, $14,50-56$.

Lizak, P. (2011). Proces kształtowania się słowackiego przemysłu motoryzacyjnego jako wyraz konkurencyjności regionu. Prace Komisji Geografii Przemystu Polskiego Towarzystwa Geograficznego, 17, 144-154.

Lung. Y., van Tulder. R. (2004). Introduction: In Search of a Viable Automobile Space. In: J. Carrillo, Y. Lung, R. van Tulder (eds.), Cars, Carriers of Regionalism? Houndmills-New York: Palgrave Macmillan, 1-20.

Łasak, P. (2013). Procesy umiędzynarodowienia przemystu samochodowego. Rola rynków wschodzacych. Kraków: Wydawnictwo Uniwersytetu Jagiellońskiego.

Miranda, A.V. (2007). La industria automotriz en México. Antecedentes, situación actual y perspectivas. Contaduría y Administración, 221, 211-248.

OICA (Organisation Internationale des Constructeurs d'Automobile) (2013). World Motor Vehicle Production by Country and Type, 1997-2012. Paris, OICA. Retrieved from www.oica.net.

Pavlínek, P. (2002). Transformation of the Central and East European passenger car industry: selective peripheral integration through foreign direct investment. Environment and Planning A, 34, $1685-1709$.

Pavlínek, P. (2008). A Successful Transformation? Restructuring of the Czech Automobile Industry. Heidelberg: Physica-Verlag.

Pavlínek, P., Domański, B., Guzik, R. (2009). Industrial Upgrading Through Foreign Direct Investment in Central European Automotive Manufacturing. European Urban and Regional Studies, 16(1), 43-63.

Pavlínek, P., Ženka, J. (2011). Upgrading in the automotive industry: firm-level evidence from Central Europe. Journal of Economic Geography, 11(3), 559-586.

Rachwał, T., Wiedermann, K. (2008). Multiplier effects in regional development: The case of the motor vehicle industry in Silesian voivodeship (Poland). Questiones Geographicae, 27B/1, 67-80.

Rachwał, T. (2003). Proces restrukturyzacji przedsiębiorstw przemysłowych w Polsce Południowo-Wschodniej (na wybranych przykładach). Prace Komisji Geografii Przemystu Polskiego Towarzystwa Geograficznego, 4, 79-88.

Rachwał, T. (2006a). Restrukturyzacja technologiczna przedsiębiorstw przemysłowych Polski Południowo-Wschodniej jako czynnik podnoszenia ich konkurencyjności na rynku międzynarodowym. Prace Komisji Geografii Przemystu Polskiego Towarzystwa Geograficznego, 8, 192203.

Rachwał, T. (2006b). Efekty restrukturyzacji wybranych przedsiębiorstw przemysłowych Polski Południowo-Wschodniej. Prace Komisji Geografii Przemystu Polskiego Towarzystwa Geograficznego, 9, 98-115.

Shapiro, H. (1991). Determinants of Firm Entry into the Brazilian Automobile Manufacturing Industry, 1956-1968. Business History Review, 65(4), 876-947.

Sturgeon, T., van Biesebroeck, J., Gereffi, G. (2008). Value chains, networks and clusters: reframing the global automotive industry. Journal of Economic Geography, 8, 297-321.

The Automotive Industry. (2013). Ministry of Economy, ProMéxico Trade and Investment, Business Intelligence Unit, Mexico D.F. Retrieved from http://www.promexico.gob.mx/work/models/promexico/Resource/447/1/images/120731_FC_The\%20Automotive\%20Industry_EN.PDF. 
van Tulder, R. (2004). Peripherial Regionalism: The Consequences of Integrating Central and Eastern Europe in the European Automobile Space. In: J. Carrillo, Y. Lung, R. van Tulder (eds.), Cars, Carriers of Regionalism? Houndmills-New York: Palgrave Macmillan, 75-90.

van Tulder, R., Audet, D. (2004). The Faster Lane of Regionalism. In: J. Carrillo, Y. Lung, R. van Tulder (eds.), Cars, Carriers of Regionalism? Houndmills-New York: Palgrave Macmillan, 23-41.

Wójtowicz, M. (2008). Rozwój przemysłu samochodowego w Brazylii w latach 1957-2005. Prace Komisji Geografii Przemystu Polskiego Towarzystwa Geograficznego, 10, 140-153.

Wójtowicz, M. (2009). Wpływ globalizacji i integracji w ramach MERCOSUR na wymianę handlową produktów przemysłu samochodowego Brazylii w latach 1990-2006. Prace Komisji Geografii Przemystu Polskiego Towarzystwa Geograficznego, 12, 63-77.

Wójtowicz, M. (2011). Wpływ światowego kryzysu gospodarczego na brazylijski i meksykański przemysł samochodowy. Prace Komisji Geografii Przemystu Polskiego Towarzystwa Geograficznego, $17,129-143$.

Wójtowicz, M. (2012). Rozwój i przekształcenia przemysłu samochodowego w Brazylii i Meksyku na przełomie XX i XXI wieku. In: M. Drgas, J. Knopek (eds.), Gospodarcze problemy Ameryki Łacińskiej. Toruń: Wydawnictwo Adam Marszałek, 161-193.

Mirosław Wójtowicz, Ph.D., Pedagogical University of Cracow, Institute of Geography, Department of Socio-Economic Geography. Ph.D. in geography (specialization in socio-economic geography), lecturer in the Department of Socio-Economic Geography at Pedagogical University in Kraków.His research interests focus on issues of urbanization and industrialization process in Latin America, with particular emphasis on Argentina, Brazil and Mexico.

Tomasz Rachwal, Ph.D., Pedagogical University of Cracow, Institute of Geography, Department of Entrepreneurship and spatial Management. Economic geographer, head of the Department of Entrepreneurship and Spatial Management - Institute of Geography, Pedagogical University of Cracow. Member of the National Council for Entrepreneurship. His research interests focus primarily on the issue of change of the spatial structures of industry, the functioning of various branches of industrial activity, corporate restructuring and the role of entrepreneurship in the development of spatial systems and entrepreneurship education.

\section{Adres/address:}

Mirosław Wójtowicz

Pedagogical University of Cracow

Department of Socio-Economic Geography

Institute of Geography

ul. Podchorążych 2, 30-084 Kraków, Poland

e-mail:mwojt@up.krakow.pl

\section{Adres/address:}

Tomasz Rachwał

Pedagogical University of Cracow

Department of Entrepreneurship and Spatial Management

Institute of Geography

ul. Podchorążych 2, 30-084 Kraków, Poland

e-mail: T.Rachwal@up.krakow.pl 